\title{
ENHANCING WAQF FOREST SUSTAINABILITY THROUGH AGROFORESTRY: CASE STUDY FROM BOGOR WAQF FOREST, BOGOR, INDONESIA
}

\author{
Miftahul Jannah, ${ }^{1 *}$ Khalifah Muhamad Ali, ${ }^{2}$ Brigita Laura Fatria, ${ }^{3}$ \\ Azila Ahmad Sarkawi ${ }^{4}$ and Jamilah Othman ${ }^{5}$
}

${ }^{1}$ International Islamic University Malaysia and BogorWaqf Forest Foundation, email:jannah.2719@gmail.com ${ }^{2} I P B$ University and BogorW aqf Forest Foundation, Indonesia, email: khalifahma@apps.ipb.ac.id

${ }^{3} I P B$ University, Indonesia, email: brigitalauraf@gmail.com

${ }^{4}$ International Islamic University Malaysia, email: azila@iium.edu.my

${ }^{5}$ International Islamic University Malaysia, email:jamilah 61164@,iium.edu.my

*Corresponding author

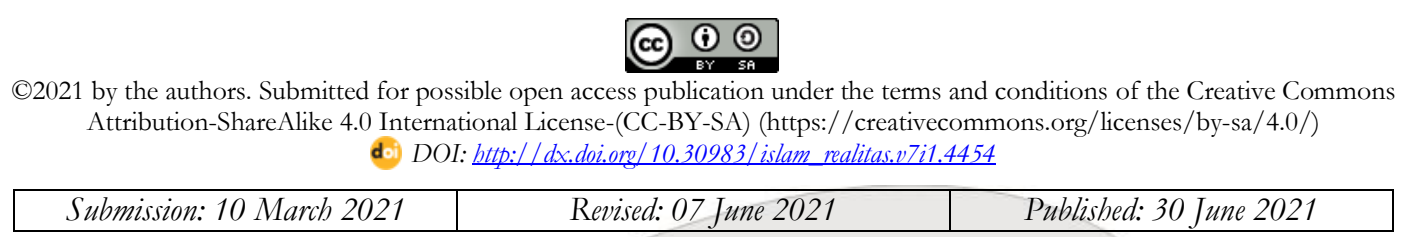

\section{Abstract}

The high rate of forest conversion in Indonesia required further actions to overcome. One of the solutions is through waqf (endowment) forest, a forest developed on waqf land. According to Islamic law, a waqf forest cannot be sold, granted, inherited, or changed unreasonably. Previous researches generally focused more on the potential and prospect of cash waqf or land waqf for forest protection. On the other hand, a study to enhancing waqf forest sustainability still needs to be developed, especially in Indonesia. This paper aims to observe the practice of agroforestry to enhance the sustainability of waqf forest, with the case study location in the Bogor Waqf Forest, Cibunian Village, Pamijahan District, Bogor Regency, Indonesia. The present study was conducted from March 2019 until June 2021, using a literature study, observation, and in-depth interview method then analyzed descriptively. Agroforestry practices are chosen in the case study location, such as agrosilvicultural, agrosilvopastoral, and agrosilvofishery. Based on the Sustainable Forest Management (SFM) goals, agroforestry practices in waqf forests are estimated to extend forest resources, increase biodiversity, forest health, forest production, and protection functions, and contribute to social and economic development benefits.

Keywords: Agroforestry; Environment; Waqf development; Waqf forest.

\section{Abstrak}

Tingginy a alihfungsi lahan butan di Indonesia memerlukan usaba lebih untuk. mengatasinya. Salah satu solusinya adalab melalui program hutan wakaf, yaitu butan yang dibangun di atas tanah wakaf. Berdasarkan hukum Islam, butan wakaf tidak boleh dijual, diberikan, diwariskan, dan diubah fungsi labannya tanpa alasan yang dibenarkan. Penelitianpenelitian sebelumnya lebib berfokus pada potensi dan prospek dari wakeaf uang atau wakaf tanah untuk melindungi butan. Studi mengenai upaya pelestarian butan wakaf masib perlu untuk dilakukan, terutama di Indonesia. Studi ini dilakukan pada bulan Maret tahun 2019 bingga Juni tahun 2021, berlokasi di Hutan Wakaf Bogor, Desa Cibunian, Pamijahan, Kabupaten Bogor, Indonesia, menggunakan metode studi literatur, observasi lapang, dan wawancara pakar yang kemudian dianalisis secara deskriptif. Beberapa praktik agroforestri dipilib untuk diaplikasikan pada lokasi studi, seperti agrosilvikultura, agrosilvopastoral, dan agrosilvofishery. Berdasarkan tujuan pengelolaan hutan lestari (SFM), praktik agroforestri pada butan wakaf diestimasikan tidak banya meningkatkan sumber daya butan, biodiversitas, kesehatan, produksi, dan perlindungan hutan, tetapi juga memiliki manfaat sosial dan ekonomi.

Kata Kunci: Agroforestri; Lingkungan; Pengembangan Wakaf; Hutan Wakaf.

\section{Background}

Forests are one of the most important ecosystems on the planet. There are at least nine essential benefits of the forest for human life, for example as a source of wood raw materials, energy sources of fuelwood and charcoal, sources of non-wood raw materials, shelter, reserves of agricultural land, watershed protection, carbon storage, biodiversity, and habitat, as well as ecotourism and recreation ${ }^{1}$. In

1 Central Bureau of Statistics, Analisis Rumah Tangga Sekitar Kawasan Hutan Di Indonesia (Badan Pusat Statistik, 2015). 
the context of the Sustainable Development Goals, forests can be a source of livelihoods, food, and medicines and produce clean water, fresh air, storing carbon, and increases biodiversity. On the other hand, forest damage can increase poverty, starvation, respiratory problems, and the destruction of infrastructures ${ }^{2}$.

Unfortunately, Indonesia's forests, the third-largest tropical rainforest after Brazil and Congo $^{3}$, are getting damaged over time. Throughout 2009-2013, deforestation reached 1.13 million hectares/year ${ }^{4}$. From 2014 to 2015, annual deforestation within the Indonesian Forest Area was 0.82 million hectares. Amongst the primary drivers were the forest fires of $2015^{5}$. Due to their needs, these deforestations are mainly caused by land-use change, natural resources exploitation for economic development, and forest encroachment by the villagers ${ }^{6}$.

There are several reasons why protecting and managing forests is essential. Managing forest is a part of preserving the environment, for example, by controlling hydrology of the watershed, flood, erosion, soil fertility, and protecting biological nature and unique natural characteristics in the interest of science, culture, national defence recreations, and tourism ${ }^{7}$.

As the largest Muslim-majority country ${ }^{8}$, Indonesia can adopt a religious way for environmental management practices ${ }^{9}$, including forest preservation. Islam cares about the environment, as stated in Qur'an surah AlAn'am verse 165, where Allah SWT remind human, as a Khalifa, to take responsibility to the environment.

"And it is He (God) who has made you successors (Khalifa) upon the earth and has raised some of you above others in degrees [of rank] that He may try you through what He has given you. Indeed, your Lord is swift in penalty; but indeed, He is Forgiving and Merciful."10

Islam has a financial instrument named waqf (Islamic endowment). Nowadays, waqf programs are pursued to improve the quality and quantity of prayer, education, or health facilities and pay attention to environmental sustainability. According to the statement before, one of the most important aspects of protecting the environment and ecology is the conservation of the trees, forests, woodlands,
${ }^{2}$ Frances Seymour and Jonah Busch, 'Forests and SDGs: Taking a Second Look | World Resources Institute', 2017, $\quad$ p. 5 <https://www.wri.org/blog/2017/09/forests-and-sdgstaking-second-look $>$.

3 Armida S Alisjahbana and Jonah M Busch, 'Forestry, Forest Fires, and Climate Change in Indonesia', Bulletin of Indonesian Economic Studies, 53.2 (2017), 111-36 <https://doi.org/10.1080/00074918.2017.1365404>.

4 FWI (Forest Watch Indonesia), Deforestasi Tanpa Henti (Bogor, Indonesia, 2018) $<$ http:/ / fwi.or.id/wp-

content/uploads/2018/03/deforestasi_tanpa_henti_201 3-2016_lowress.pdf $>$.

${ }^{5}$ Ministry of Environment and Forestry, The State of Indonesia's Forests 2018 (Jakarta: Ministry of Environment and Forestry, Republic of Indonesia, 2018).

${ }^{6}$ Tatan Sukwika and others, 'Skenario Kebijakan

Pengelolaan Hutan Rakyat Berkelanjutan Di Kabupaten Bogor', Jurnal Pengelolaan Sumberdaya Alam Dan Lingkungan (Journal of Natural Resources and Environmental Management), 8.2 (2018), 207-15 $<$ https://doi.org/10.29244/jpsl.8.2.207-215>.
7 Harry Santoso, Forest Area Rationalization in Indonesia: A Study on The Forest Resource Condition and Policy Reform (Bogor: World Agroforestry Centre (ICRAF), 2003).

8 Jeff Diamant, 'The Countries with the 10 Largest Christian Populations and the 10 Largest Muslim Populations,, Pew Research Center, 2019, pp. 1-5 $<$ https://www.pewresearch.org/fact$\operatorname{tank} / 2019 / 04 / 01 /$ the-countries-with-the-10-largestchristian-populations-and-the-10-largest-muslimpopulations / > [accessed 29 September 2019].

9 Misbah Alghamdi, 'Deforestation and the Islamic Stewardship Ethic' (Rochester Institute of Technology, 2014)

<http://gradworks.umi.com/15/61/1561422.html>; Mochammad Arif Budiman, 'The Role of Waqf for Environmental Protection in Indonesia', in Aceb Development International Conference 2011, 2011, pp. 880-89.

10 Saheeh International Translation, The Our'an with Surah Introductions and Appendices, ed. by A. B. AlMehri (Birmingham: Maktabah Booksellers and Publishers, 2010) < http://quran.com/1>. 
countryside, and all living creatures whose habitats are such areas ${ }^{11}$.

Waqf can be used to preserve the forest in the form of a waqf forest. Waqf forest is a forest developed on waqf land ${ }^{12}$. In line with that, it is inevitable that after a land/forest is set and registered as a waqf forest, it would remain as a forest until the end of the world. Land use cannot be changed into another function, such as mining or housing. This waqf forest needs to be productively maintained, so it can meet the primary purpose of waqf, "hold the principal and spread the benefits." ${ }^{13}$. One of the essential requirements is a strategic plan for the waqf assets to stay productive to keep the waqf sustainable ${ }^{14}$.

Previous research about waqf for forest preservation generally focused on the concept and its financial aspects. For example, cash waqf might be beneficial for protecting the forest and urban forest ${ }^{15}$. Also, the waqf forest might be essential in preserving the forest and supporting $\mathrm{SDGs}^{16}$. Meanwhile, a detailed discussion about enhancing the sustainability of waqf assets for forest preservation still needs to be developed, especially in Indonesia. Some of the research questions are, 1) What kind of approach needed to be done by the waqf forest nazhir to enhance its sustainability?, 2) Is there any example of the agroforestry practices in the waqf forest?, and 3)
Is there any benefits that can be described from the agroforestry practices in the waqf forest?

This study aims to observe agroforestry to improve the sustainability of waqf forest, with the case study in the Bogor Waqf Forest, Cibunian Village, Pamijahan, Bogor Regency, Indonesia. The discussion in this paper will be divided into several sections. The first section is an introduction, focusing on Islam's potential to overcome the forest problems in Indonesia, primarily through waqf. The second part will discuss further waqf for environmental preservation in Indonesia. The following discussion part will be focused on the practice of waqf forests in Indonesia. Then, it will explain the agroforestry in Islam and its practices in Indonesia. The fifth section will discuss the application of agroforestry in the case study area (Bogor Waqf Forest). After that, the expected benefits will be presented with Sustainable Forest Management (SFM) parameters. Finally, it will end with a conclusion and recommendations for further studies.

\section{Waqf for Environmental Preservation in Indonesia}

As an old Islamic tradition, waqf is flexible and can be adapted to respond to the needs of society. The natural environment could be one
${ }^{11}$ Ibrahim Ozdemir, 'An Islamic Approach to the Environment', Environment-Ecology.Com, 2002 $<$ http://www.environment-ecology.com/religion-andecology/489-an-islamic-approach-to-theenvironment.pdf $>$ [accessed 10 April 2019].

12 Khalifah Muhamad Ali and Miftahul Jannah, 'Model Pengembangan Hutan Wakaf', Republika (Jakarta Selatan, 2019), p. 18

13 Khalifah Muhamad Ali, 'Wakaf Untuk Pengelolaan Hutan Yang Berkelanjutan', Https://Sharianews.Com, 2018, pp. 1-8 $<$ https://sharianews.com/posts/wakaf-untukpengelolaan-hutan-yang-berkelanjutan $>$ [accessed 20 June 2019].

14 Tika Widiastuti and Wahyuningsih, Waqf Productive Efficiency: Evidence From Yayasan Badan Wakaf Sultan Agung, Semarang', Advances in Social Science, Education and Humanities Research (ASSEHR), 98.Icpsuas
2017 (2018), 178-85 < https://doi.org/10.2991/icpsuas17.2018.39>

${ }^{15}$ Idaul Hasanah and Rahmad Hakim, 'Pelestarian Hutan Kota Melalui Optimalisasi Wakaf Tunai (Conservation of Urban Forest through Optimization of Cash Waqf)', Prosiding Seminar Nasional III Tabun 2017, Biologi, Pembelajaran, Dan Lingkungan Hidup Perspektif Indisipliner', April, 2017, 345-49; Adzidah Yaakob and others, 'Waqf as a Means of Forest Conservation: Alternative for Malaysia', Advanced Science Letters, 23.5 (2017),

4860-64 <https://doi.org/10.1166/asl.2017.8928>.

16 Khalifah Muhamad Ali and Salina Kassim, 'Waqf Forest: How Waqf Can Play a Role In Forest Preservation and SDGs Achievement?', ETIKONOMI, $19.2 \quad$ (2020), 349-64 <https://doi.org/10.15408/etk.v19i2.16310>. 
of the beneficiaries of the waqf $f^{17}$. The past evidence of waqf development shows that the donors can decide on various types of action, including religious and general projects ${ }^{18}$. Given the emergence of environmental conditions today, waqif is expected to start directing the goals of waqf on environmental protection projects $^{19}$.

In Indonesia, some Islamic organizations are already trying to establish a waqf for the environment. For example, Tabung Wakaf Indonesia (TWI) by Dompet Dhuafa, Republika, in 2007, launched the "Tree Waqf" program $^{20}$. PP Muhammadiyyah, through its Environmental Institute in 2010, made a "Muhammadiyyah Citizenship and Tree Planting Movement" program to overcome the problem of increasing emissions ${ }^{21}$. Badan Wakaf Al-Qur'an (BWA) has also built wells to provide clean water to the local community ${ }^{22}$.

Meanwhile, The Indonesian Council of Ulamas (MUI) issued eight fatwas on the environment. Some of the fatwas are banned forest burning, illegal mining, and illegal logging in South Kalimantan in 2006. The other example, written in collaboration with the Ministry of the Environment in 2011, contained a more detailed set of applied guidelines at the national level. These fatwas represent recent initiatives involving religious principles as stimuli for behavioral change, preventing environmental destruction in Indonesia ${ }^{23}$.

\section{Waqf for Forest Preservation in Indonesia}

Allah SW'T created the first man (Adam as) to live in heaven. Physically, the human character must have been adjusted by the heavenly environment ${ }^{24}$, which, according to the Qur'an, is described as gardens with trees, running water, and other natural environments ${ }^{25}$. So, it is believed that forests, as one of the natural environments on earth, certainly have a deep connection with human life $^{26}$.

Allah SWT gives human beings unique abilities, such as thinking, speaking, and planning. But, the human started using his skills for gaining temporary benefits and facilities, which resulted in the loss of resistance to natural resources. There must be a force to control any type of mischiefs, including destructing forest, as stated in the Qur'an, surah Ali Imran verse 104,

"Here has to be a group of people from among you who call towards the good and bid the fair and the unfair. And these are the once who are successful."27

In Indonesia, several actions of waqf for forest conservation already started in the form of a waqf forest. Waqf forest is a forest built on
${ }^{17}$ Eisa Al-Anzi and Nada. Al-Duaij, 'Islamic Waqf and Environmental Protection', Codicillus, 45.2 (2004), 52-63.

18 Anwar Allah Pitchay, Ahmad Kameel Mydin Meera, and Muhammad Yusuf Saleem, 'Priority of Waqf Development among Malaysian Cash Waqf Donors : An AHP Approach', Journal of Islamic Finance, 3.1 (2014), 1322 <https://doi.org/2289-2117 (O) / 2289-2109 (P)>.

$19 \mathrm{Al}$-Anzi and Al-Duaij.

20 Magda Ismail Abdel Mohsin, 'Financing through Cash-Waqf: A Revitalization to Finance Different Needs', International Journal of Islamic and Middle Eastern Finance and Management, 6.4 (2013), 304-21 <https://doi.org/10.1108/IMEFM-08-2013-0094>.

21 Humas BWI, 'Muhammadiyah Canangkan Gerakan Wakaf Pohon', Bwi.Go.Id, 2010 <https://www.bwi.go.id/427/2010/03/berita/berita- wakaf/muhammadiyah-canangkan-gerakan-wakafpohon/ > [accessed 20 May 2019].

${ }^{22}$ Yaakob and others.

$23 \mathrm{JE}$ (Editor) MCKay, Integrating Religion Within Conservation: Islamic Beliefs and Sumatran Forest Management (Kent, United Kingdom: Durrell Institute of Conservation and Ecology, 2013).

24 Abad-ur-Rahman and Muhammad Ayaz, 'Sustainable Conservation of Forests: Islamic Guidelines', Dialogue: A Quarterly Research Journal, 11 iv, 2015, 444-49.

25 Miftahul Jannah, Wahju Qamara Mugnisjah, and Andi Gunawan, 'Kajian Konsep Taman Islam Berdasarkan Al-Quran Dan Hadits', El-Harakah, 17.1 (2015), 1-17.

${ }^{26}$ Abad-ur-Rahman and Ayaz.

27 Saheeh International Translation, The Qur'an with Surab Introductions and Appendices, ed. by A. B. AlMehri (Birmingham: Maktabah Booksellers and Publishers, 2010) <http://quran.com/1>. 
private land, not on government-owned land or customary land. The existence of forests constructed on land that has been used as waqf will guarantee the sustainability of the forest because waqf has unique characteristics: it may not be sold, inherited, and granted. The ownership of the waqf forest has moved from private to Allah SWT and utilized for the public interest ${ }^{28}$.

The first Waqf Forest in Indonesia, called "Hutan Wakaf Jantho," located in Aceh Province, found in 2012. There are also "Wakaf Leuweung Sabilulungan," located in the critical land, proposed by the local government of Bandung District. A waqf forest is located in Cibunian Village, Pamijahan District, Bogor Regency, established by some scholars from IPB University ${ }^{29}$.

\section{The Concept of Agroforestry in Islam and Its Practice in Indonesia}

Agroforestry is the interaction between agriculture and trees, including trees on farms and agricultural landscapes, farming in forests and forest margins, and tree-crop production, including cocoa, coffee, rubber, and oil palm ${ }^{30}$. Agroforestry can be one solution to make a community forest profitable from the beginning, without damaging the wood itself ${ }^{31}$. Agroforestry can shift land demand and provide alternative products otherwise derived from forest over-exploitation or conversion, thereby avoiding leakage from forest protection efforts $^{32}$. The latest research ensures that growing more trees on agricultural land will increase biodiversity and farmers' livelihoods ${ }^{33}$.

28 Ali and Jannah.

${ }^{29}$ Ali and Kassim, 'Waqf Forest: How Waqf Can

Play a Role In Forest Preservation and SDGs Achievement?'

30 ICRAF, 'What Is Agroforestry?', World Agroforestry, 2004, 7-12 $<$ https://doi.org/10.1007/bf00044325>.

31 Khalifah Muhamad Ali, 'Strategi Pengembangan Hutan Rakyat Melalui Pendayagunaan Zakat: Kasus Di Desa Karyasari, Kecamatan Leuwiliang, Kabupaten Bogor' (IPB University, 2009).
Although it is not explicitly stated as 'agroforestry,' in the Qur'an, there are several verses that describe that on one land, there can be several types of plants at the same time. It is as mentioned in Surah Ar-Ra'du verse 4,

"And within the land are neighboring plots and gardens of grapevines and crops and palm trees, [growing] several from a root or otherwise, watered with one water; but We make some of them exceed others in [quality of] fruit. Indeed in that are signs for a people who reason." 34

In the verses of the Qur'an, it is said that there are vineyards and date palms in one land, irrigated from the same source. The same thing is also mentioned in the Quran surah Al-Kahfi verses 32-34,

"And present to them an example of two men: We granted to one of them two gardens of grapevines, and We bordered them with palm trees and placed between them [fields of] crops. Each of the two gardens produced its fruit and did not fall short thereof in anything. And We caused to gush forth within them a river. And he had fruit, so he said to his companion while he was conversing with him, "I am greater than you in wealth and mightier in [numbers of] men." 35

The two verses above describe the variety of plants in agricultural activities. Mohammad Al-Shaykh, an agricultural scholar, said Surah Al Kahfi verses 32-33 inspired planting patterns. The successive planting patterns are dates (tree species), grapes (vines), crop fields, grapes, and more in one area. The linkages of plant variations mentioned in Surah Al-Kahfi will be beneficial for increasing agricultural yields.

32 Peter A. Minang and others, 'Prospects for Agroforestry in REDD+ Landscapes in Africa', Current Opinion in Environmental Sustainability, 6.1 (2014), 78-82 <https://doi.org/10.1016/j.cosust.2013.10.015>.

33 Rob Finlayson, 'Agroforestry World Blog', Agroforestry World, 2018, pp. 1-30 <blog.worldagroforestry.org/index.php/2018/09/03/in donesia-looking-to-protect-biodiversity-through-treeson-farms/> [accessed 28 September 2019].

${ }^{34}$ Saheeh International Translation.

35 Saheeh International Translation. 
Furthermore, it was also explained that this planting pattern was more profitable in climate and affected soil quality ${ }^{36}$.

Muhaimin Iqbal, the directorate of Gerai Dinar, in his articles, explains that there are seven levels of plants mentioned in various verses in the Qur'an. Those seven levels are canopy tree/large fruit and nut tree (dates, as in Ar-Ra'du:4), low tree/dwarf fruit tree (olive, pomegranate, or figs), shrub layer (raibaan, as in Ar-Rahman:12), herbaceous, rhizosphere/root crops (for example ginger, as in Al-Insan:17), soil surface/ground cover (as in 'Abasa:31), and vertical/climber/vines (for example grape, as in Al-An'am:161). The mention of the seven levels of plants in the Qur'an is a picture of food forest or agroforestry ${ }^{37}$

Previous studies indicate that palm trees have become a key species in agroforestry practices in the African and South Asian areas. This palm tree acts as a protector, a barrier against the sting of the desert sun. Underneath, there are many species of plants, depending on the weather. The plants include apricot, mulberry, grape, figs, pomegranate, banana, et cetera $^{38}$. In Morrocco, for example, there is a 2000-year-old food forest. The forest is becoming a source of food security for 800

${ }^{36}$ Nadiah Thayyarah, Buku Pintar Sains Dalam AlOur'an (Mausu'ah Al-I'jaz Al-Qur'ani), ed. by Chairul Ahmad, Dar Al- Yamama, Abu Dhabi (Jakarta Selatan: Penerbit Zaman, 2014).

37 Muhaimin Iqbal, 'Agroforestry Untuk Mengentaskan Kemiskinan', Hidayatullah.Com, 2013 <https://www.hidayatullah.com/kolom/ilahiyahfinance/read/2013/07/02/5296/agroforestry-untukmengentaskan-kemiskinan.html> [accessed 20 April 2020].

38 Eric Toensmeier, The Carbon Farming Solution (White River Junction, Vermont: Chelsea Green Publishing, 2016).

39 Eric J. Wallace, 'The Moroccan Food Forest That Inspired an Agricultural Revolution', Gastro Obscura, 2019,

$$
\text { p. }
$$

$<$ https://www.atlasobscura.com/articles/what-ispermaculture-food-forests $>$ [accessed 27 May 2020].

${ }^{40}$ Iqbal.

${ }^{41}$ H. De Foresta et al., "Ketika Kebun Berupa Hutan, Agroforest Khas Indonesia: Sebuah Sumbangan Masyarakat", ICRAF (International Centre for Research families of farmers ${ }^{39}$. Multispecies and stratified planting patterns are one of the strengths that keep Morrocan Food Forest sustainable ${ }^{40}$.

In Indonesia, generally, there are two types of agroforestry, namely simple and complex agroforestry. An example of simple agroforestry is agrisilvicultural. It combines forestry plants and horticultural crops with specific cropping patterns ${ }^{41}$. One example of complex agroforestry is a random mixture of planting many trees, shrubs, and seasonal plants or grass in one land to resemble a primary or secondary nature reserve forest ${ }^{42}$.

Agroforestry has been practised widely by the Indonesian community for centuries ago. There are several different names for agroforestry in Indonesia, for example, mratani in Java, dusung in Maluku, repong in Lampung, reba juma in North Sumatera, and tembawang in West Borneo ${ }^{43}$. A lot of researches have been done about agroforestry practices in Indonesia. For example, in Berau, East Kalimantan, the Kampung Birang plant langsat as its main agroforestry commodity, while the Kampung Merabu plant rubber and some durian species ${ }^{44}$.

The agroforestry practices also include a combination of crops, forestry, and livestock (agrosilvopastoral) ${ }^{45}$. This practice is suitable in

in Agroforestry) (Bogor, indonesia: SMT Grafika Desa Putera, 2000).

42 Yuyun Yuwariyah AS, 'Potensi Agroforestry Untuk Meningkatkan Pendapatan Kemandirian Bangsa Dan Perbaikan Lingkungan', Mycological Research, 113.2 (2009), 207-21.

43 Ary Widiyanto, 'Agroforestry Dan Peranannya Dalam Mempertahankan Fungsi Hidrologi Dan Konservasi', Al-Basia, 9.2 (2013), 55-68 <https://www.researchgate.net/publication/300142098 $>$.

44 Adisti Permatasari Putri Hartoyo and others, 'Biodiversity, Carbon Stocks and Community Monitoring in Traditional Agroforestry Practices: Preliminary Results from Two Investigated Villages in Berau, East Kalimantan', Procedia Environmental Sciences, 33 (2016), 376-85

<https://doi.org/10.1016/j.proenv.2016.03.088>

45 Cheikh Mbow and others, 'Agroforestry Solutions to Address Food Security and Climate Change Challenges in Africa', Current Opinion in Environmental 
areas where people are active in the livestock business but have limited grazing land ${ }^{46}$. The agrosilvopastoral practice has become a tradition in various regions in Indonesia, one of which is in West Sumatra because it is supported by natural conditions (topography and agricultural resources) ${ }^{47}$. Another model of agrosilvopastoral is the combination of forestry, agriculture, and fish farming (agrosilvofishery). This model has also been developed in various regions in Indonesia and has been proven to contribute to farmers' income, for example, in Deli Serdang, North Sumatra ${ }^{48}$.

Enhancing Waqf Forest Sustainability through Agroforestry: Case Study of Bogor Waqf Forest

This section will explain the application of the concept of agroforestry in the case study location. The application plan includes a brief site inventory and analysis, also a description of the agroforestry practices.

\section{Site Inventory and Analysis}

The Bogor Waqf Forest consists of 3 areas in Cibunian Village, Pamijahan District, Bogor Regency, Indonesia, with approximately
9530 m3. Cibunian Village bordered Purasari village in the north and west, and Kali Cianteun Village in the south ${ }^{49}$. Located between $0-1000$ $m$ altitudes, Cibunian Village generally has various slopes, from 8 to $40 \%$. The village mostly contained alluvial and andosol soil ${ }^{50}$. The most common land use per 2016 is a rice crop. There are around 2383 families lives in Cibunian Village; some of their everyday life is as a sharecropper ${ }^{51}$. The majority of the population responded positively to the reforestation and forest conservation effort at their place ${ }^{52}$.

The Bogor Waqf Forest Foundation manages the Bogor Waqf Forest as a nazhir. This foundation already has a legal entity, which is one of its strengths because, without a legal nazhir organization, a waqf asset can be disrupted in the future ${ }^{53}$. The three Bogor Waqf Forest areas also have waqf pledge deeds (AIW/Akta Ikrar Wakaf) managed at the KUA of Pamijahan District in 2020 and 2021. The waqf pledge deed is one of the essential legalities because this deed makes the waqf forest officially registered as one of the waqf assets by the state ${ }^{54}$.
Sustainability,

6.1

(2014),

$61-67$

<https://doi.org/10.1016/j.cosust.2013.10.014>.

46 Yuwariyah AS.

47 Fitrimawati and I Adnani, 'Sustainability and Agrosilvopastoral Development Model: Farmers Perceptions and Supporting Factors in West Sumatera, Indonesia', Indian Horticulture Journal, 10.1/2 (2020), 0105

<https://www.indianjournals.com/ijor.aspx?target=ijor: ihj1\&volume $=10 \&$ issue $=1$ and $2 \&$ article $=001>$.

48 Abdul Rauf, Rahmawaty, and Dewi Budiati T. J. Said, 'Sistem Pertanian Terpadu Di Lahan Pekarangan Mendukung Ketahanan Pangan Berkelanjutan Dan Berwawasan Lingkungan', Jurnal Pertanian Tropik, 1.1 (2013)

<https://doi.org/https://doi.org/10.32734/jpt.v1i1.28 $64>$.

49 Diskominfo Kabupaten Bogor, 'Profil Desa Cibunian', Kecamatanpamijahan.Bogorkab.Go.Id, 2019, p. 8640509

<https://kecamatanpamijahan.bogorkab.go.id/desa/19 1> [accessed 25 August 2021].

50 Ana Mariana Ulfah Rahayu, 'Studi Tingkat Kerawanan Longsor Di Kecamatan Pamijahan
Kabupaten Bogor (Study of the Landslide Vulnerability Level in Pamijahan Bogor District)' (UIN Syarif Hidayatullah Jakarta, 2016).

${ }^{51}$ Diskominfo Kabupaten Bogor.

52 Ahmad Lutfi, Mulyadi At, and Bambang Supriono, 'Persepsi Dan Partisipasi Masyarakat Dalam Kegiatan Rehabilitasi Hutan Dan Lahan Di Kabupaten Bogor (Perception and Participation of the Community in the Rehabilitation of Forest and Land Areas Bogor Regency)', Jurnal Nusa Sylva, 14.1 (2014), 32-42.

53 Khalifah Muhamad Ali and Salina Kassim, 'Development of Waqf Forest in Indonesia : The SWOTANP Analysis of Bogor Waqf Forest Program by Bogor Waqf Forest Foundation', Jurnal Manajemen Hutan Tropikea (Journal of Tropical Forest Management), 27.2 (2021), 89-99 <https://doi.org/10.7226/jtfm.27.2.89>.

54 Miftahul Jannah, Azila Ahmad Sarkawi, and Jamilah Othman, 'Legalization of Waqf Forests in Indonesia : A Registration Process', Indonesia Law Review, 10.3

<https://doi.org/http://dx.doi.org/10.15742/ilrev.v10 n3.629>. 
Cibunian Village is one area with a high natural disasters vulnerability (landslides) ${ }^{55}$. The existence of waqf forests is not only expected to reduce potential disasters (ecological benefits). It is also expected to provide economic and social benefits for local communities as the most essential mauquf 'alaih. One of the ways is by implementing agroforestry practices.

\section{Agroforestry Practices in the Bogor Waqf Forest}

Based on the field observation and interview, there are three types of agroforestry practices in the Bogor Waqf Forest, namely agrosilvicultural (mixed crops), agrosilvopastoral (sheep and stingless bee), and agrosilvofishery (carp).

\section{a. Agrosilvicultural}

Agrosilvicultural is an agroforestry practice that combines forestry and horticultural crops ${ }^{56}$. In Bogor Waqf Forest, this practice is carried out in areas 1 and 2 .

Waqf Forest Area 1 was previously a paddy field; there were no trees. In addition to the forestry tree planting activities, local communities also use the unshaded areas to plant various seasonal crops. They planted several commodities such as corn (Zea mays) and other vegetables in 2019.

In 2021, the Waqf Forest 1 area already covered by the trees planted before. Therefore, vegetables that can grow optimally under shade were selected, such as bok choi (Brassica rapa). The Giat Bersama farmer group has harvested vegetables several times, and each family can utilize the commodity (Figure 1).

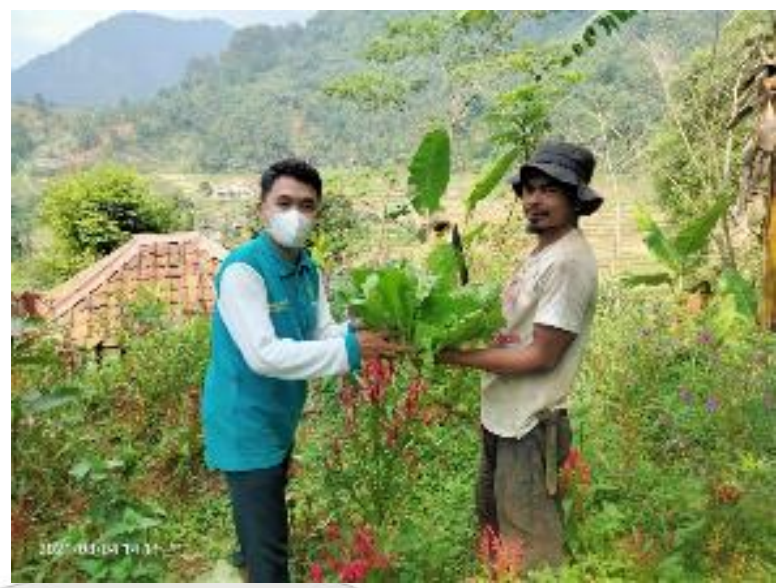

Figure 1. Harvesting bok choi (Brassica rapa)

Agroforestry practices are also carried out in the Waqf Forest area 2. When land ownership is transferred from private land to waqf forest, the existing trees are maintained, including clove (Sysygium aromaticum) trees. Planting horticultural commodities is done by choosing species that can survive under the shade, such as chives (Allium schoenoprasum).

\section{b. Agrosilvopastoral}

Agrosilvopastoral is an agroforestry practice that combines forestry crops with livestock ${ }^{57}$. Two types of livestock are bred under the shade of trees in Waqf Forests 1 and 2 , namely sheep and stingless bees.

Sheep is one of the primary livestock commodities in Bogor Regency, including Cibunian Village ${ }^{58}$. Therefore, in general, local people already have skills in sheep cultivation. The agrosilvopastoral sheep practice is carried out in the Bogor Waqf Forest 2 by providing access to the community to build cages and raise their sheep in the waqf forest area. In addition, during the sheep selling season (Idul Adha), the Bogor Waqf Forest Foundation as the nazhir helped farmers sell the sheep.
55 Ardi Chandra Yunianto, 'Analsis Kerawanan Tanah Longsor Dengan Aplikasi Sistem Informasi Geografis (SIG) Dan Penginderaan Jauh Di Kabupaten Bogor' (IPB University, 2011).

56 Yuwariyah AS.
${ }^{57}$ Mbow and others.

${ }^{58}$ L Cyrilla, Z Moesa, and S M P Putri, 'Efisiensi Produksi Usaha Peternakan Domba Di Desa Cibunian Kecamatan Pamijahan Kabupaten Bogor', Media Peternakan, 33.1 (2010), 55-60. 


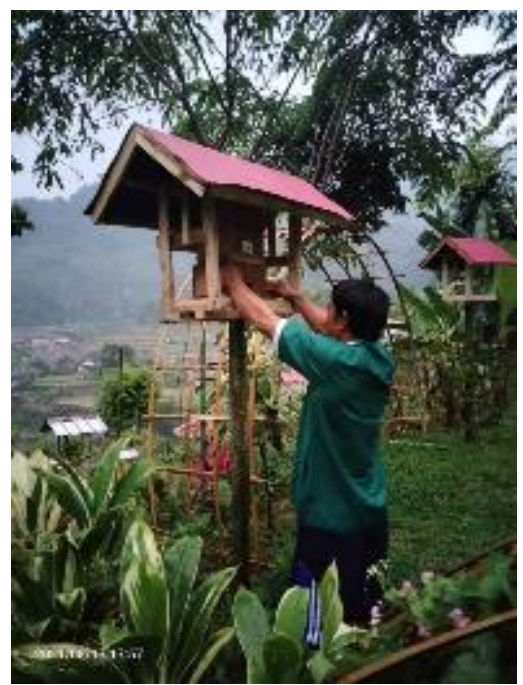

Figure 2. The stingless bee nest

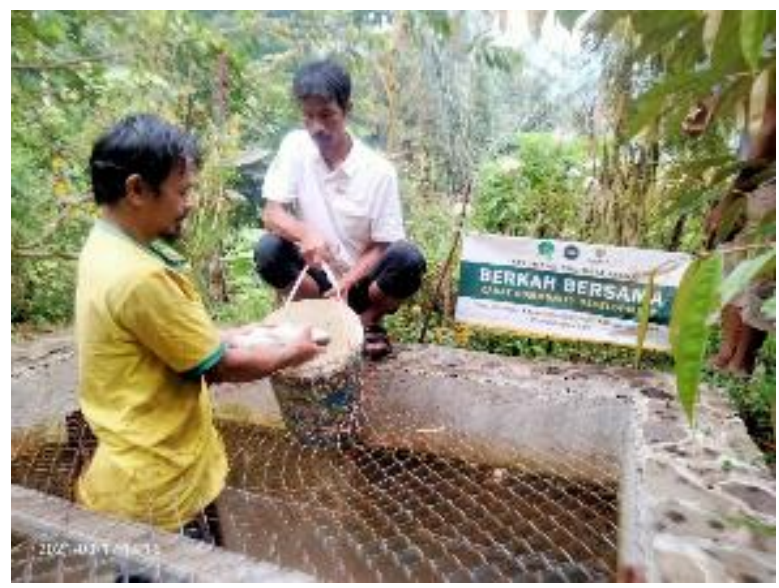

Figure 3. Harvesting carp

\section{Expected Benefits of Agroforestry Practice in the Bogor Waqf Forest}

The application of agroforestry in waqf forests is expected to enhance the sustainability of waqf forests. Based on the global criteria for Sustainable Forest Management (SFM), there are seven criteria for sustainable forest management. Those globally approved measures for SFM are, 1) extent of forest resources, 2) biological diversity, 3) forest health and vitality, 4) productive functions of the forest, 5) protective functions of the forest, 6) socio-economic benefits and needs, and 7) legal, policy, and institutional framework ${ }^{60}$. How agroforestry can play a role in these seven points in the Bogor Waqf Forest will be explained below.

\section{The Extent of Forest Resources}

The Bogor Waqf Forest is located in an area that used to function as agricultural land. Waqf will ensure that the land will continue to be developed as a forest forever. It will, of course, extend to the forest resources. Agroforestry practices on waqf forest land would provide additional forest products
${ }^{59}$ Rauf, Rahmawaty, and Said.

60 F Castaneda, 'Criteria and Indicators for Sustainable Forest Management: International Processes,
Current Status and the Way Ahead', Unasylva, 51.203 (2000), 34-40. 
harvested annually and become a source of capital to develop the waqf forest ${ }^{61}$.

Based on the interview and observation results, in Cibunian Village outside the Bogor Waqf Forest area, agroforestry practices have been carried out by a small number of farmers. However, the lack of forest location makes agroforestry practice unable to be done by many local communities. The waqf forests as an agroforestry location have been proven to provide additional non-timber forest products beneficial to local communities in the form of horticultural products and livestock.

\section{Biological Diversity}

At present, the vegetation in Cibunian Village is dominated by plantation and wet tropical forest plants. The conversion of the forest into a farm by the local community has reduced the total population of forest vegetation $^{62}$. Reforestation activities will undoubtedly be able to increase biodiversity again.

Agroforestry will increase biological diversity because the trees will provide natural elements and shelters for economically important species $^{63}$. Agroforests are a valuable collection of germplasm and a new sanctuary for many wild non-economic species, which survive even though their natural habitat is destroyed $^{64}$.

\section{Forest Health and Vitality}

The existing condition of Cibunian Village, which generally had a high slope, was potentially prone to landslides during the rainy season $^{65}$. Therefore, conservation efforts need to be considered. Vegetative conservation methods can be carried out at the site by using plants to reduce the destructive force of falling water and reduce water flow's amount and destructive power at the soil's surface.

The agroforestry activities carried out in the Bogor Waqf Forest are sought to support the sustainability of the forest. The choice of horticultural crops is adjusted to the conditions of the forest land, so there is no need to cut down existing trees. The selection of stingless bees as one of the livestock commodities is also intended to maintain forest sustainability. It requires planting various plants as a food source for the bee, reflecting on its honey quality ${ }^{66}$.

\section{The Productive Function of Forests}

Agroforestry may be varying forest products that can be harvested by the farmers, even giving opportunities to develop valuable new commodities that are compatible with other crops. Agroforestry can also support various ecosystem services such as pollination, which can produce some food plants ${ }^{67}$.

In Indonesia, agroforestry practices are still often underestimated. They are considered to reduce the value of the primary commodity compared to the monoculture system. For example, the agroforest rubber commodities may be only half or one-third of monoculture rubber. However, 'other crop disturbance' in agroforest rubber can be valued high in another point. For example, they can supply fruits, vegetables, medicinal plants, and other needs to meet nutritional needs and maintain family health $^{68}$. In line with that, non-timber forest
${ }^{61}$ Khalifah Muhamad Ali, 'Hutan Wakaf : Solusi Melestarikan Rimba (Waqf Forest: Solution for Forest Sustainability)', Forest Digest (Bogor, 2019), pp. 54-55.

62 Iffah Rahmaniyah, 'Perencanaan Lanskap Agrowisata Dusun Muara Satu Desa Cibunian Kecamatan Pamijahan Kabupaten Bogor (Landscape Planning of Agritourism on Dusun Muara Satu, Cibunian Village Pamijahan District, Bogor Regency)' (IPB University, 2014).

${ }^{63}$ Hartoyo and others.

${ }^{64}$ Foresta and others.
${ }^{65}$ Rahmaniyah.

66 Suelen Ávila and others, 'Stingless Bee Honey : Quality Parameters, Bioactive Compounds, HealthPromotion Properties and Modification Detection Strategies', Trends in Food Science \& Technology, 81.March (2018), $37-50$

<https://doi.org/10.1016/j.tifs.2018.09.002>.

${ }^{67}$ R. Jamnadass and others, Agroforestry, Food and Nutritional Security, Unasylva, 2013, LXIV.

${ }^{68}$ Foresta and others. 
products from agroforestry also have a high return, even becoming the primary income source for the local communities ${ }^{69}$.

Agroforestry practices in the Bogor Waqf Forest are expected to not only be able to provide farmers with alternative commodities for sale other than agricultural products but also to make Waqf Forests productive to meet the community's daily needs. Based on the results of interviews and observations, several agroforestry products (vegetables, fish, and sheep) have been successfully harvested by mauqufalaihi and become another source of income.

\section{The Protective Function of Forests}

Agroforestry can shift land demand and provide alternative products otherwise derived from forest over-exploitation or conversion, thereby avoiding leakage from forest protection efforts ${ }^{70}$. Various plants will be planted in one land in agroforestry practices, including trees with deep roots and many leaves. Even this plant type could hold the soil in its place, reduce run-off, and prevent landslides ${ }^{71}$.

Based on interviews with key people in Cibunian Village, many forests in the village area have been converted into land by residents because of economic needs. The urgency of meeting daily needs conquers the interests of protecting forests, so they encroach the forest to fulfill their daily needs. The agroforestry practice in the waqf forest will save the wood while still trying to reach the living needs of the surrounding community.

\section{Socio-Economic Benefits and Needs}

Agroforestry raises farmers' incomes by selling tree products and surplus staples ${ }^{72}$. Shreds of evidence prove that agroforestry systems provide a higher income than the monoculture one, for example, in Northern $\operatorname{Iran}^{73}$. In Africa, agroforestry already established its real potential contribution to food security, also mitigation, and adaptation of climate change while at the same time preserving and strengthening the environmental resource base ${ }^{74}$.

In Bogor Waqf Forest, agroforestry practices have been proven to provide economic and social benefits. Currently, two farmer groups are cultivating the Bogor Waqf Forest, namely the Giat Bersama and Berkah Bersama groups. The Giat Bersama farmer group has benefited economically from selling sheep and harvesting vegetables. Meanwhile, Berkah Bersama farmer groups have experienced economic benefits from the sale of carp.

In addition, under the shade of trees in the Bogor Waqf Forest, various social activities were also carried out, including empowering women, conservation-based children's educational activities, and learning to read and write the Qur'an.

\section{Legal, Policy, and Institutional Framework}

The forest should be sustainable as a waqf forest because it cannot be changed, sold, or inherited based on Islamic law ${ }^{75}$. Forests built on waqf land will have the power to remain a

Landslide Potency In Bogor Regency)' (IPB University, 2008).

72 Jamnadass and others, LXIV.

${ }^{73}$ M Mohebi Bijarpas, T Rostami Shahraji, and S Prospects of Non Timber Forest Products in Community Agroforestry Land Around Sibolangit Tourism Park', Forest and Society, $1.1 \quad$ (2017), 68 $<$ https://doi.org/10.24259/fs.v1i1.1096>.

${ }^{70}$ Minang and others.

71 Fheny Fuzi Lestari, 'Penerapan Sistem Informasi Geografis Dalam Pemetaan Daerah Rawan Longsor Di Kabupaten Bogor (Geographic Information System Application In Mapping Areas With A Certain Of
Mohammadi Limaei, 'Socioeconomic Evaluation of Agroforestry Systems (Case Study: Northern Iran)', Journal of Forest Science, 61.11 (2015), 478-84 <https://doi.org/10.17221/30/2015-JFS>.

${ }^{74}$ Mbow and others.

${ }^{75}$ Jannah, Sarkawi, and Othman. 
forest from two sides, the Islamic religious regulation $^{76}$, and the country's legal law ${ }^{77}$. The combination of the two acts already listed in the laws of the Republic of Indonesia, supported by agroforestry practices that ensure the sustainability of the benefits of waqf forest, will significantly strengthen and influence the existence of waqf forests forever.

In addition, the waqf forest is a productive waqf. A productive waqf must be appropriately managed so that it can benefit the surrounding community. For example, waqf forest management can help finance those in need through legal and halal channels. In addition, legal Waqf Forest Management can also help the marketing of agroforestry products be more widespread and practical.

\section{Conclusion}

Agroforestry practice can be chosen to enhance the Waqf Forest sustainability, for example, in the form of agrosilvicultural, agrosilvopastory, and agrosilvifoshery. Several benefits are expected based on SFM criteria. It includes as extent forest resources, increasing biodiversity, forest health, forest production, and protection functions. Agroforestry in the waqf forest is also expected to contribute to the social and economic benefits for the community near the forest, and the effects shall be sustainable as the forest itself. Therefore, among the suggestion for future studies are,

1. financial and farming analysis for all commodities to ensure the economic value received by farmers through products planted in waqf forests, and

2. further studies on other agroforestry practices that can be done, which can provide more excellent value.

\section{References}

\section{Book}

Foresta, H De, A Kusworo, G Michon, and WA Djatmiko, Ketika Kebun Berupa Hutan, Agroforest Khas Indoesia: Sebuah Sumbangan Masyarakat, ICRAF (International Centre for Research in Agroforestry) (Bogor, indonesia: SMT Grafika Desa Putera, 2000) <https://doi.org/10.1017/CBO9781107 415324.004>

Jamnadass, R., F. Place, E. Torquebiau, E. Malézieux, M. Iiyama, G. W. Sileshi, and others, Agroforestry, Food and Nutritional Security, Unasylva, 2013, LXIV

MCKay, JE (Editor), Integrating Religion Within Conservation: Islamic Beliefs and Sumatran Forest Management (Kent, United Kingdom: Durrell Institute of Conservation and Ecology, 2013)

Ministry of Environment and Forestry, The State of Indonesia's Forests 2018 (Jakarta: Ministry of Environment and Forestry, Republic of Indonesia, 2018)

Saheeh International Translation, The Qur'an with Surah Introductions and Appendices, ed. by A. B. Al-Mehri (Birmingham: Maktabah Booksellers and Publishers, 2010) $<$ http://quran.com/1>

Santoso, Harry, Forest Area Rationalization in Indonesia: A Study on The Forest Resource Condition and Policy Reform (Bogor: World Agroforestry Centre (ICRAF), 2003)

Thayyarah, Nadiah, Buku Pintar Sains Dalam AlQur'an (Mausu'ah Al-I'jaz Al-Qur'ani), ed. by Chairul Ahmad, Dar Al- Yamama, Abu Dhabi (Jakarta Selatan: Penerbit Zaman, 2014)

Toensmeier, Eric, The Carbon Farming Solution (White River Junction, Vermont: Chelsea Green Publishing, 2016)

\section{Journal}

Abad-ur-Rahman, and Muhammad Ayaz, 'Sustainable Conservation of Forests: Islamic Guidelines', Dialogue: A Quarterly Research Journal, 11 iv, 2015, 444-49

Affandi, Oding, Anita Zaitunah, and Ridwanti

${ }^{77}$ Indonesia, Law of the Republic of Indonesia Number

${ }^{76}$ Indonesia, Law of the Republic of Indonesia Number 41 of 2004 about Waqf (Indonesia: Ministry of Religious Affairs, 2004), pp. 1-27.
41 of 1999 Concerning Forestry (Indonesia, 1999). 
Batubara, 'Potential Economic and Development Prospects of Non Timber Forest Products in Community Agroforestry Land Around Sibolangit Tourism Park', Forest and Society, 1.1 (2017), 68

<https://doi.org/10.24259/fs.v1i1.1096 $>$

Al-Anzi, Eisa, and Nada. Al-Duaij, 'Islamic Waqf and Environmental Protection', Codicillus, 45.2 (2004), 52-63

Ali, Khalifah Muhamad, and Salina Kassim, 'Development of Waqf Forest in Indonesia : The SWOT-ANP Analysis of Bogor Waqf Forest Program by Bogor Waqf Forest Foundation', Jurnal Manajemen Hutan Tropika (Journal of Tropical Forest Management), 27.2 (2021), 89-99 $<$ https://doi.org/10.7226/jtfm.27.2.89> , 'Waqf Forest: How Waqf Can Play a Role In Forest Preservation and SDGs Achievement?', ETIKONOMI, 19.2 (2020), 349-64 $<$ https://doi.org/10.15408/etk.v19i2.163 $10>$

Alisjahbana, Armida S, and Jonah M Busch, 'Forestry, Forest Fires, and Climate Change in Indonesia', Bulletin of Indonesian Economic Studies, 53.2 (2017), 111-36 $<$ https://doi.org/10.1080/00074918.201 7.1365404>

Ávila, Suelen, Márcia Regina Beux, Rosemary Hoffmann Ribani, and Rui Carlos Zambiazi, 'Stingless Bee Honey : Quality Parameters, Bioactive Compounds, Health- Promotion Properties and Modification Detection Strategies', Trends in Food Science \& Technology, 81.March (2018), $\quad 37-50$ $<$ https://doi.org/10.1016/j.tifs.2018.09.0 $02>$

Bijarpas, M Mohebi, T Rostami Shahraji, and S Mohammadi Limaei, 'Socioeconomic Evaluation of Agroforestry Systems (Case Study : Northern Iran)', Journal of Forest Science, $\quad 61.11 \quad$ (2015), $\quad 478-84$ $<$ https://doi.org/10.17221/30/2015JFS $>$

Budiman, Mochammad Arif, 'The Role of Waqf for Environmental Protection in
Indonesia', in Aceh Development International Conference 2011, 2011, pp. 880-89

Castaneda, F, 'Criteria and Indicators for Sustainable Forest Management: International Processes, Current Status and the Way Ahead', Unasylva, 51.203 (2000), 34-40

Cyrilla, L, Z Moesa, and S M P Putri, 'Efisiensi Produksi Usaha Peternakan Domba Di Desa Cibunian Kecamatan Pamijahan Kabupaten Bogor', Media Peternakan, 33.1 (2010), 55-60

Fitrimawati, and I Adnani, 'Sustainability and Agrosilvopastoral Development Model: Farmers Perceptions and Supporting Factors in West Sumatera, Indonesia', Indian Horticulture Journal, 10.1/2 (2020), 01-05

$<$ https://www.indianjournals.com/ijor.as px? target $=$ ijor:ihj $1 \&$ volume $=10 \&$ issue $=1$ and $2 \&$ article $=001>$

Hartoyo, Adisti Permatasari Putri, Iskandar Z. Siregar, Supriyanto, Lilik B. Prasetyo, and Ida Thelaide, 'Biodiversity, Carbon Stocks and Community Monitoring in Traditional Agroforestry Practices: Preliminary Results from Two Investigated Villages in Berau, East Kalimantan', Procedia Environmental Sciences, 33 (2016), 376-85 $<$ https://doi.org/10.1016/j.proenv.2016. 03.088>

Hasanah, Idaul, and Rahmad Hakim, 'Pelestarian Hutan Kota Melalui Optimalisasi Wakaf Tunai', Prosiding Seminar Nasional III Tabun 2017, Biologi, Pembelajaran, Dan Lingkungan Hidup Perspektif Indisipliner', April, 2017, 345-49

Jannah, Miftahul, Wahju Qamara Mugnisjah, and Andi Gunawan, 'Kajian Konsep Taman Islam Berdasarkan Al-Quran Dan Hadits', El-Harakah, 17.1 (2015), 1-17

Jannah, Miftahul, Azila Ahmad Sarkawi, and Jamilah Othman, 'Legalization of Waqf Forests in Indonesia : A Registration Process', Indonesia Law Review, 10.3 (2020) <https://doi.org/http://dx.doi.org/10.1 5742/ilrev.v10n3.629>

Lutfi, Ahmad, Mulyadi At, and Bambang Supriono, 'Persepsi Dan Partisipasi Masyarakat Dalam Kegiatan Rehabilitasi Hutan Dan Lahan Di Kabupaten Bogor', 
Jurnal Nusa Sylva, 14.1 (2014), 32-42

Mbow, Cheikh, Meine Van Noordwijk, Eike Luedeling, Henry Neufeldt, Peter A. Minang, and Godwin Kowero, 'Agroforestry Solutions to Address Food Security and Climate Change Challenges in Africa', Current Opinion in Environmental Sustainability, $6.1 \quad$ (2014), 61-67 <https://doi.org/10.1016/j.cosust.2013.1 $0.014>$

Minang, Peter A., Lalisa A. Duguma, Florence Bernard, Ole Mertz, and Meine van Noordwijk, 'Prospects for Agroforestry in REDD+ Landscapes in Africa', Current Opinion in Environmental Sustainability, 6.1 (2014), 78-82 <https://doi.org/10.1016/j.cosust.2013.1 $0.015>$

Mohsin, Magda Ismail Abdel, 'Financing through Cash-Waqf : A Revitalization to Finance Different Needs', International Journal of Islamic and Middle Eastern Finance and Management, 6.4 (2013), 304-21 <https://doi.org/10.1108/IMEFM-082013-0094>

Pitchay, Anwar Allah, Ahmad Kameel Mydin Meera, and Muhammad Yusuf Saleem, 'Priority of Waqf Development among Malaysian Cash Waqf Donors : An AHP Approach', Journal of Islamic Finance, 3.1 (2014), 13-22 < https://doi.org/2289$2117(\mathrm{O}) / 2289-2109(\mathrm{P})>$

Rauf, Abdul, Rahmawaty, and Dewi Budiati T. J. Said, 'Sistem Pertanian Terpadu Di Lahan Pekarangan Mendukung Ketahanan Pangan Berkelanjutan Dan Berwawasan Lingkungan', Jurnal Pertanian Tropik, 1.1 (2013), $1-8$ $<$ https://doi.org/https://doi.org/10.327 34/jpt.v1i1.2864>

Sukwika, Tatan, Dudung Darusman, Cecep Kusmana, and Dodik Ridho Nurrochmat, 'Skenario Kebijakan Pengelolaan Hutan Rakyat Berkelanjutan Di Kabupaten Bogor', Jurnal Pengelolaan Sumberdaya Alam Dan Lingkungan (Journal of Natural Resources and Environmental Management), 8.2 (2018), 207-15

$<$ https://doi.org/10.29244/jpsl.8.2.207215>

Widiastuti, Tika, and Wahyuningsih, 'Waqf
Productive Efficiency: Evidence From Yayasan Badan Wakaf Sultan Agung, Semarang', Advances in Social Science, Education and Humanities Research (ASSEHR), 98.Icpsuas 2017 (2018), 17885 <https://doi.org/10.2991/icpsuas17.2018.39>

Widiyanto, Ary, 'Agroforestry Dan Peranannya Dalam Mempertahankan Fungsi Hidrologi Dan Konservasi', Al-Basia, 9.2 (2013), 5568

$<$ https://www.researchgate.net/publicati on/300142098>

Yaakob, Adzidah, Nurnadiah Mahzir, Dina Imam Supaat, Mohamad Zaharuddin Zakaria, Izawati Wook, and Maizatun Mustafa, Waqf as a Means of Forest Conservation: Alternative for Malaysia, Advanced Science Letters, 23.5 (2017), 486064

<https://doi.org/10.1166/asl.2017.8928 $>$

Yuwariyah AS, Yuyun, Potensi Agroforestry Untuk Meningkatkan Pendapatan Kemandirian Bangsa Dan Perbaikan Lingkungan', Mycological Research, 113.2 (2009), 207-21

\section{Thesis and Dissertation}

Ali, Khalifah Muhamad, 'Strategi Pengembangan Hutan Rakyat Melalui Pendayagunaan Zakat: Kasus Di Desa Karyasari, Kecamatan Leuwiliang, Kabupaten Bogor' (IPB University, 2009)

Lestari, Fheny Fuzi, 'Penerapan Sistem Informasi Geografis Dalam Pemetaan Daerah Rawan Longsor Di Kabupaten Bogor' (IPB University, 2008)

Rahayu, Ana Mariana Ulfah, 'Studi Tingkat Kerawanan Longsor Di Kecamatan Pamijahan Kabupaten Bogor' (UIN Syarif Hidayatullah Jakarta, 2016)

Rahmaniyah, Iffah, 'Perencanaan Lanskap Agrowisata Dusun Muara Satu Desa Cibunian Kecamatan Pamijahan Kabupaten Bogor' (IPB University, 2014)

Yunianto, Ardi Chandra, 'Analsis Kerawanan Tanah Longsor Dengan Aplikasi Sistem Informasi Geografis (SIG) Dan Penginderaan Jauh Di Kabupaten Bogor' (IPB University, 2011) 
Articles in Newspapers and Magazines

Ali, Khalifah Muhamad, 'Hutan Wakaf : Solusi Melestarikan Rimba', Forest Digest (Bogor, 2019), pp. 54-55

_ Yang Berkelanjutan', Https://Sharianews.Com, 2018, pp. 1-8 $<$ https://sharianews.com/posts/wakafuntuk-pengelolaan-hutan-yangberkelanjutan> [accessed 20 June 2019]

Ali, Khalifah Muhamad, and Miftahul Jannah, 'Model Pengembangan Hutan Wakaf, Republika (Jakarta Selatan, 2019), p. 18

\section{Online database}

Central Bureau of Statistics, Analisis Rumah Tangga Sekitar Kawasan Hutan Di Indonesia (Badan Pusat Statistik, 2015)

Diamant, Jeff, 'The Countries with the 10 Largest Christian Populations and the 10 Largest Muslim Populations', Pew Research Center, 2019, pp. 1-5 $<$ https://www.pewresearch.org/facttank/2019/04/01/the-countries-withthe-10-largest-christian-populations-andthe-10-largest-muslim-populations/> [accessed 29 September 2019]

Diskominfo Kabupaten Bogor, 'Profil Desa Cibunian',

Kecamatanpamijahan.Bogorkab.Go.Id, 2019, p. 8640509

$<$ https://kecamatanpamijahan.bogorkab. go.id/desa/191> [accessed 25 August 2021]

Finlayson, Rob, 'Agroforestry World Blog', Agroforestry World, 2018, pp. 1-30 $<$ blog.worldagroforestry.org/index.php/ 2018/09/03/indonesia-looking-toprotect-biodiversity-through-trees-onfarms / > [accessed 28 September 2019]

\section{Digital and social media}

Alghamdi, Misbah, 'Deforestation and the Islamic Stewardship Ethic' (Rochester Institute of Technology, 2014) $<$ http://gradworks.umi.com/15/61/156 1422.html>

FWI (Forest Watch Indonesia), Deforestasi Tanpa Henti (Bogor, Indonesia, 2018) $<$ http:// fwi.or.id/wpcontent/uploads/2018/03/deforestasi_ta npa_henti_2013-2016_lowress.pdf>

Humas BWI, 'Muhammadiyah Canangkan Gerakan Wakaf, Bwi.Go.Id, 2010 <https://www.bwi.go.id/427/2010/03/ berita/berita-wakaf/muhammadiyahcanangkan-gerakan-wakaf-pohon/> [accessed 20 May 2019]

ICRAF, 'What Is Agroforestry?', World Agroforestry, 2004, 7-12 <https://doi.org/10.1007/bf00044325>

Iqbal, Muhaimin, 'Agroforestry Untuk Mengentaskan Kemiskinan', Hidayatullah.Com, 2013 <https://www.hidayatullah.com/kolom/ ilahiyahfinance/read/2013/07/02/5296/agrofor estry-untuk-mengentaskan-

kemiskinan.html> [accessed 20 April 2020]

Ozdemir, Ibrahim, 'An Islamic Approach to the Environment', Environment-Ecology.Com, $2002<$ http://www.environmentecology.com/religion-and-ecology/489an-islamic-approach-to-theenvironment.pdf $>$ [accessed 10 April 2019]

Seymour, Frances, and Jonah Busch, 'Forests and SDGs: Taking a Second Look | World Resources Institute', 2017, p. 5 <https://www.wri.org/blog/2017/09/fo rests-and-sdgs-taking-second-look $>$

Wallace, Eric J., 'The Moroccan Food Forest That Inspired an Agricultural Revolution', Gastro Obscura, 2019, p. 2020 $<$ https://www.atlasobscura.com/articles /what-is-permaculture-food-forests> [accessed 27 May 2020]

\section{Law}

Indonesia, Law of the Republic of Indonesia Number 41 of 1999 Concerning Forestry (Indonesia, 1999) , Law of the Republic of Indonesia Number 41 of 2004 about Waqf (Indonesia: Ministry of Religious Affairs, 2004), pp. 1-27 